\title{
Les roys de Engeltere: An illustrated genealogy for King Edward I
}

\author{
Andrew N.J. Dunning
}

The series of images of English kings from Edward the Confessor to Edward I in London, British Library, Cotton MS Vitellius A. XIII/1 is widely familiar from television, textbooks, websites, and exhibitions. In spite of this, the origins and context of this set of four leaves are mysterious. The limited attention given to them has focused on the images rather than the Anglo-Norman captions attached to them, which forms a genealogy of the kings, derived from earlier sources.

The focus on Edward I implies that he was somehow linked with the leaves' production, and their style of writing and illustration is consistent with the time of his reign $(1272-1307) .{ }^{1}$ Beyond this, nothing is known of their origin. The mystery of these leaves results from their complete detachment from a historical context. They were collected by Sir Robert Bruce Cotton, who combined them with unrelated texts as his manuscript Vitellius A. XIII. ${ }^{2}$ Fols 91-100 are known to have come from the royal library. ${ }^{3}$ This is typical of Cotton's practices, which is characterized more

*Thanks to Chantry Westwell, Daron Burrows, and Judith Collard for their comments on this paper.

1 The manuscript has been described in Sonja Drimmer, 'Images of English Kings, from Edward the Confessor to Edward I', in Royal Manuscripts: The Genius of Illumination, ed. Scot McKendrick, John Lowden, and Kathleen Doyle (London, 2011), pp. 340-1; Lucy Freeman Sandler, Gothic Manuscripts, 1285-1385, Survey of Manuscripts Illuminated in the British Isles, v (2 vols, London, 1986), no. 9; Thomas Duffus Hardy, Descriptive Catalogue of Materials Relating to the History of Great Britain and Ireland, to the End of the Reign of Henry VII, Rolls Series, xxvi (3 vols, London, 1862), nos. 316, 516; A Catalogue of the Manuscripts in the Cottonian Library Deposited in the British Museum, ed. Joseph Planta (London, 1802), p. 380.

2 Colin G.C. Tite, The Early Records of Sir Robert Cotton's Library: Formation, Cataloguing, Use (London, 2003), p. 159 gives evidence for provenance.

3 James P. Carley, The Libraries of King Henry VIII, Corpus of British Medieval Library Catalogues, vii (London, 2000), pp. lxxxiii, H2.847; James P. Carley, 'The Royal Library as a Source for Sir Robert Cotton's Collection: A Preliminary List of Acquisitions', The British Library Journal, xviii (1992), pp. 52-73 (pp. 65-6). 
by connoisseurship than historical preservation. ${ }^{4}$

The leaves are now separate from the rest of Cotton's compilation. The Ashburnham House fire on 23 October 1731 damaged the book, and conservators later mounted its leaves on paper; the maximum size of original parchment as preserved is $204 \times 147 \mathrm{~mm}$. The leaves were removed from the rest of the volume in January 1939 for exhibition, and more recently given the separate shelfmark Cotton MS Vitellius A. XIII/1. They are now housed separately in glass frames, along with five pieces of fabric that were once curtains for the miniatures; these were still attached in the nineteenth century. ${ }^{5}$

The work itself has occasionally been called Effigies regum Angliae (Portraits of Kings of England), ${ }^{6}$ quoting the table of contents added by Cotton's librarian, Richard James (fol. 2r), but this is merely his description. It seems more appropriate to refer to it by an Anglo-Norman title: the opening line of the text furnishes an obvious choice, Les roys de Engeltere (The Kings of England).

The leaves are presumably fragments of a more extensive manuscript. The most widely posited theory has been that they prefaced a historiographical work, similar to the portraits of English kings found in Matthew Paris's Historia Anglorum (Royal MS 14 C. vII) and Abbreuiato chronicorum (Cotton MS Claudius D. vI). ${ }^{7}$ Unlike these and other similar examples, however, the images unusually mark time by focusing on the deaths of kings, especially in the cases of Richard I and John, rather than showing them enthroned. ${ }^{8}$ The comparatively small size of the leaves has also led to the theory that they might have opened a personal liturgical book, with the style of decoration specifically compared to the Peterborough Psalter (Brussels,

4 Michelle P. Brown, 'Sir Robert Cotton, Collector and Connoisseur?', in Illuminating the Book: Makers and Interpreters: Essays in Honour of Janet Backhouse, ed. Michelle P. Brown and Scot McKendrick, The British Library Studies in Medieval Culture (London, 1998), pp. 281-98; Sir Robert Cotton as Collector: Essays on an Early Stuart Courtier and His Legacy, ed. C.J. Wright (London, 1997); James P. Carley and Colin G.C. Tite, 'Sir Robert Cotton as Collector of Manuscripts and the Question of Dismemberment: British Library MSS Royal ${ }_{13}$ D. I and Cotton Otho D. VIII', The Library, 6th ser., xiv (1992), pp. 94-9.

5 Joseph Strutt, The Regal and Ecclesiastical Antiquities of England, ed. J.R. Planché (new ed., London, 1842), p. 3, n. 1 describes them as 'a sort of fine tissue paper, which has been placed as a guard to the illuminations'.

6 This appears to have begun with Georg Vitzthum, Die Pariser Miniaturmalerei von der Zeit des hl. Ludwig bis zu Philipp von Valois und ihr Verhältnis zur Malerei in Nordwesteuropa (Leipzig, 1907), p. 68.

7 Judith Collard, 'Effigies ad Regem Angliae and the Representation of Kingship in ThirteenthCentury English Royal Culture', Electronic British Library Journal, 2007, p. 2.

8 Paul Binski, Westminster Abbey and the Plantagenets: Kingship and the Representation of Power, 1200-1400 (New Haven, CT, 1995), p. 126. 
KBR, MS 9961-62). ${ }^{9}$ It is unknown what texts (if any) the original compilers meant their work to accompany, or indeed what their audience might have been. It could be interpreted as either an outward suggestion of how the monarchy wished to be viewed, or a book commissioned as a gift to royalty, perhaps similar to the 'certain book on the deeds of the kings of England' ('quodam libro de Gestis Regum Anglie') that Edward I purchased for his eldest son in February $1301 .{ }^{10}$

The portraits feature Edward the Confessor (fol. 3r), Harold and William the Conqueror (fol. 3v), William II and Henry I (fol. 4r), Stephen and Henry II (fol. 4v), Richard I (fol. 5r), John (fol. 5v), Henry III (fol. 6r), and Edward I (fol. 6v). Edward the Confessor is given the most extensive treatment of any of the kings. After him, Harold and William the Conqueror are illustrated with a scene from the Battle of Hastings, while the monarchs up to Richard I are given a summary and only a half-page portrait, the primary point being their existence. Richard I, John, and Henry III are embellished with full-page portraits and more detailed accounts of their accomplishments. The caption for Edward I was never completed: there is a capital A executed in gold leaf, but the text was never added, showing that the captions were added to the pages after the illustrations were completed.

The tight-lipped captions defy any attempt to define its audience. It does not portray the kings as universally wise. The kings' relations with the church are ambiguous: the martyrdom of Thomas Becket is stated as a matter of fact; the text mourns the chalices sold off for the ransom of Richard I and almost portray the king as an unnecessary burden; and it is unclear whether readers should despise or celebrate the monk who poisoned John, or even believe that he committed this. What is explicit in the text is the relentless, inevitable succession of monarchs. It naturally takes the Norman side in the conquest: and William was only taking what was his by right; and the Anarchy of $1135-53$ is entirely glossed over. The text's primary aim is the unstoppable character of the English monarchy and more specifically the celebration of Edward I's legitimate genealogy and his right to be king.

The text shows that this focus is entirely appropriate, as it is closely linked to the tradition of genealogical rolls, particularly popular during Edward's reign. It has already been pointed out that the text has parallels with other rolls and chronicles of the period. ${ }^{11}$ It bears particular resemblance to the work usually

9 Sandler, Gothic Manuscripts, nos. 9, 40; Collard, 'Effigies', pp. 11-3.

10 Wardrobe book, 29 Edward I: British Library, Add. MS 7966A, fol. 31r, cited in Susan H. Cavanaugh, 'Royal Books: King John to Richard II', The Library, 6th ser., x (1988), pp. $304-16$ (p. 308); Hilda Johnstone, Edward of Carnarvon, 1284-1307 (Manchester, 1946), p. 18; Drimmer, 'Images of English Kings', p. 341 suggests the connection with this manuscript.

11 Ruth J. Dean, Anglo-Norman Literature: A Guide to Texts and Manuscripts, Anglo-Norman Text 
known as Le liuere de reis de Brittanie ( $L R B) .{ }^{12}$ This title was given to it by its nineteenth-century editor, based on the opening rubric to a manuscript from Trinity College, Cambridge, which can be identified as R.14.7, fol. 163r. ${ }^{13}$ The work has also been edited under the name Li rei de Engleterre. ${ }^{14}$ This popular text was widely repurposed for genealogies, ${ }^{15}$ and is highly fluid.

Because of the many variants of $L R B$, it is difficult to determine exactly how the text was adopted. There are nearly fifty known manuscripts, ${ }^{16}$ and the most recent edition covers only a fraction of these. ${ }^{17}$ The Vitellius text is particularly similar to the version as edited by Glover. ${ }^{18}$ Unfortunately, he does not cite shelfmarks in his text, saying only that he used manuscripts at Corpus Christi College and Trinity College in Cambridge, Oxford, and the British Museum. ${ }^{19}$ Of other published manuscripts, Les Roys is most similar to Cambridge, MA, Harvard Law School, MS 1, fol. xiiir, which however does not extend to Edward I. ${ }^{20}$

Les Roys appears to be for the most part an abridgement of $L R B$, but its fluidity combined with the lack of a critical edition inhibits precise understanding of how its creators might have adapted the text. Most notably, its account of Edward the Confessor does not appear in known versions of $L R B$, suggesting that the creators truly did amplify him as a progenitor of Edward I. Nearly all the details of the remaining kings, however, can be found in one of the versions of $L R B$, often with nearly identical wording. Without knowing exactly how the variant recensions of $L R B$ relate to one another, it cannot yet be said whether or not Les roys used a version extended to Edward I. Glover's version concludes, 'Apres li fust Edward sun fiz rey, e corone a Westmoster, e conquist tote la seignourize de Wales.' ${ }^{21}$ This is a plausible caption to the image in Vitellius, which shows the king facing disputing

Society Occasional Publications Series, iii (London, 1999), no. 31.

12 Dean, Anglo-Norman Literature, no. 13.

13 'Isci comence le liuere de reis de Brit': John Glover, Le livere de reis de Brittanie e Le livere de reis de Engleterre, Rolls Series, xlii (London, 1865), pp. 2-31.

14 Christian Foltys, Kritische Ausgabe der anglonormannischen Chroniken: Brutus, Li rei de Engleterre, Le livere de Reis de Engleterre (Berlin, 1962), pp. 57-114; another version, Diana B. Tyson, 'An Early French Prose History of the Kings of England', Romania, xcvi (1975), pp. 1-26.

15 John Spence, Reimagining History in Anglo-Norman Prose Chronicles (Woodbridge, Suffolk, 2013), p. 13.

16 List in Sharon K. Goetz, 'Textual Portability and Its Uses in England, ca. 1250-1330' (PhD diss., University of California, Berkeley, 2007), pp. 258-84.

17 Listed in Foltys, Kritische Ausgabe der anglonormannischen Chroniken, pp. 13-7.

18 Glover, Le livere, pp. 28-31.

19 Glover, Le livere, p. xiii.

20 Variants in Foltys, Kritische Ausgabe der anglonormannischen Chroniken, pp. 104-14; the relevant text is also transcribed in Goetz, 'Textual Portability and Its Uses in England, ca. 1250-1330', pp. 233-4.

21 Glover, Le livere, p. 30. 
bishops and courtiers; parallels to this can be found in several other contemporary historiographical works. ${ }^{22}$ On the other hand, if the source for Les roys lacked any details on Edward I, this might explain why his caption was left unfinished. At this stage, one cannot indeed say that it used $L R B$ directly, or in one of its many adaptations. These can, however, be securely claimed as the text's direct influence. Even small details that do not appear in $L R B$, such as the description of Harold as reigning 'a forz e a tort' (fol. $3 \mathrm{v}$ ), can be shown to be commonplace in contemporary genealogical or chronicle rolls. ${ }^{23}$

Although the text was probably added to the Vitellius manuscript after the images were completed, the images follow the text precisely, and help in some cases to form a more accurate comprehension of what they depict. The image of Richard I (fol. 5v) has, without the aid of the text, been interpreted as a depiction of 'an ideal knight', and a threefold scene: showing him imprisoned; being rescued from prison by Blondel de Nesle; and finally. ${ }^{24}$ This interpretation overlooks the arrow through Richard's shoulder, which is now somewhat obscured by a modern repair, and the text leads to a different interpretation of the image. It emphasizes the sacrifices made by the English in ransoming Richard, which would make the appearance of Blondel highly unusual. More accurately, the scene should be described as showing the king imprisoned at Dürnstein, while on the right an arrow has shot through his right shoulder at the castle of Chalus; the figure with him is probably Mercadier or Marchades, who accompanies the king at the castle in Roger of Howden's account of his death. ${ }^{25}$ The inclusion of the verse pun, 'Christe tui calicis, ${ }^{26}$ is a key feature of the version of $L R B$ from which Les roys appears to be derived. It was a favourite with chroniclers, and is quoted as early as Gerald of Wales in De principis instructione 3.30. ${ }^{27}$ The roots of Les roys de Engeltere reach far, and can be found as much in scholasticism as anything else.

Cotton MS Vitellius A. XIII/ 1 is an example of direct reception of the Anglo-Latin and Anglo-Norman tradition of prose chronicles, using particularly the work widely known as Le livere de reis de Brittanie. Whether its text was abridged directly from one of its versions, or was first filtered through one of the many other works derived

22 Michael Michael, 'The Iconography of Kingship in the Walter of Milemete Treatise', Journal of the Warburg and Courtauld Institutes, lvii (1994), pp. 35-47 (p. 44), n. 64.

23 Spence, Reimagining History in Anglo-Norman Prose Chronicles, p. 111.

24 Collard, 'Effigies', pp. 21-5.

25 Chronica magistri Rogeri de Houedene, ed. William Stubbs, Rolls Series, li (4 vols, London, 1868-1871), iv, p. 82; The Annals of Roger de Hoveden, tr. Henry T. Riley (2 vols, London, 1853), ii, p. 452.

26 Hans Walther, Initia carminum ac versuum medii aevi posterioris Latinorum, Carmina medii aevi posterioris Latina, i (2nd edn., Göttingen, 1969), no. 2719.

27 De principis instructione liber, vol. 8 of Giraldi Cambrensis opera, ed. George F. Warner, Rolls Series, xxi (London, 1891), p. 176. 
from it, will be knowable once the relationships between the many manuscripts of this text are better understood. As it stands, this source shows that most of the ambiguities present in Les roys - such as the monarchy's bond or lack thereof with the church and the English people, the function of a king, or methods of coping with contested successions - have been inherited by this manuscript, and cannot be used alone to determine its audience or history. The manuscript is an attempt to show the right of Edward I to his throne, and its redeployment of contemporary traditions for this end is entirely successful.

\section{Edition of Les roys de Engeltere}

Joseph Strutt made engravings from Vitellius A. XIII and several other illuminated manuscripts in the eighteenth century, and printed the text within his descriptions of the images. ${ }^{28}$ He released a new edition in 1793, adding translations, by which time he was returning to antiquarianism after financial troubles and family tragedies. ${ }^{29}$ A revision by James Robinson Planché with coloured engravings, evidently based on a new assessment of the manuscripts, appeared in 1842; he left the text unchanged but added his own observations as notes to Strutt's text. As a matter of historical interest, Planché frequently disagrees with the earlier descriptions of the manuscripts' colours: Strutt tended to describe them in somewhat duller tones than we would now, perhaps reflective of the changing environment at the British Museum. Modern scholarship on the manuscript has overlooked this publication.

Strutt is now a crucial witness to the manuscript, as it suffered further damage between 1773 and 1842. Text on fol. $3 \mathrm{r}$ that he could read had disappeared by the time Planché examined it. ${ }^{30}$ His text is largely accurate, but includes several errors, as does his translation.

This edition aims to present a corrected text of Les roys de Engeltere, following the manuscript as closely as possible. Spelling and letterforms are printed as they appear in the original, and have not been regularized for modern usage. Punctuation has been emended slightly, but follows the scheme of the original. Letters that are known only from Strutt's work, and can no longer be read due to damage, are here printed in square brackets. Editorial additions are printed in angle brackets, while modifications necessary for the sense of the text are reported in the notes.

28 Joseph Strutt, The Regal and Ecclesiastical Antiquities of England (London, 1773), nos. 2-7, 10-3. 29 Jennifer Harris, 'Strutt, Joseph (1749-1802)', in Oxford Dictionary of National Biography, ed. H.C.G. Matthew and Brian Howard Harrison (Oxford, 2004).

30 Strutt, The Regal and Ecclesiastical Antiquities of England (1842), p. 4, n. 1. 
$|3 r|$ Iscy sunt les Roys de Engeltere del tens seynt Edwarde le confessur ieske al tens le Roy Edwarde fiz al Roy Henri le tyerz.

Seynt Edwarde par la grace deu vist le Iour de paske al manger les vii. dormanz $\mathrm{tu}[\mathrm{rner}$ lur] destre costez sur [lu] rse[nestre] en [g]r[e. E cet iour Godwyne Conte] de Kent [mor] ust a [la] ta[ble estr]angle de vn morsel. Mult grant myracles [fut] deu pur luy en sa uie e apres.

Le an del incarnacion nostre seignur:.m.lxvi. e de soen reaume .xxiiii. deuant sa mort deuisa seynt Edwarde le reaume de Engeltere a Willam Bastarde soen neuou. a dunke duke de Normundye: E puis morut seynt Edwarde: e gyst enfertre ${ }^{31}$ a Westmuster.

$|3 \mathrm{v}|$ Apres seynt Edwarde regna Harald le fiz Godewyn. Count de Kent. a forz e a tort .ix. moys. Dunke veent Will' Bastarde. e ly tolyst la vye e le regne e conquist la tere. Harald gist a Waltham.

Puis regna Will' Bastard .xxi. an. puis morust. e gist a Kame en $\mathrm{N}$ [or] mundye.

$|4 \mathrm{r}|$ Apres Willam Bastard regna Will' le Rous sun fiz. Il fust berse ${ }^{32}$ en la nouele forest. Puis morust. e gist a Wyncestre. Il fist fere la grande sale de Westmuster. e regna .xii. aunz.

Apres Will' le Rous regna la primer Henry sun frere .xxxvi. aunz. Il fit les bones lays de Engleter si les enchartera. Il gist al Abbaye de Redynges. Son cors leua seynte Thomas de tere e le myst deuaunt le haut auter.

$|4 \mathrm{v}|$ Apres Henry regna Esteuen sun neuou .xix. anz e morust. e gyst a Fauersham.

Apres Esteuen regna le secund Henry fiz de sa sorour Lemperice le quele Henry lors estoyt duke ${ }^{33}$ de Normundy e en sun tens fu seynt Thomas martyrize. e regna .xxvi. ou .xxxv. aunz. puis morust e gist a Frunt Euerarde.

$\mid$ sr $\mid$ Apres Henry le secund regna Richard sun fiz .x. aunz e demy $\langle$.$\rangle Il en repayrand$ de la tere seynt fust pris del duke de Ostriz par eyde del Roy Phylippe de Fraunce. e fust reynt hors de prison pur Cent mil lyueres de argent. e pur cel rauncun furent les Chaliz de Engletere pris des Eglyses e venduz. Puis fust tret de vn quarel de Alblast al Chastel de Chalezun. dunt ceste vers fu fet: Criste tui calicis: predo fit preda Calucis.

31 corrected from enferter $M S$

32 corrected from berge $M S$

33 corrected from dunke $M S$ 
$|5 \mathrm{v}|$ Apres Richard regna Ion sun frere en ky tens Engletere fust entredyt .vi. aunz e .iii. quarters e .i. moys par la Pape Innocent pur mestre Esteuen de Langetonn. ke le Roy ne vout receyuere a Erceueke de Kaunterbyrs. Si estoyt dunke le grant guere entre ly e les Barons norrays $\langle$.$\rangle Dunt veent Sir Lowys fiz le Roy Phylippe de Fraunce$ en Engletere. Le Roy Ion regna .xvii. aunz e demy. puis veent a Swynesheued e fust enpoysone par vne frere de la meson si come fu dit. e le Roy morut a Neuwerke e sun cors fust enterre a Wyrcestre.

|6r| Apres Ion regna Henry le terz sun fiz .lvi. aunz. si fust de .ix. aunz de age quant fust corone. E en sun tens fust la bataylle de Euesham. ou fust occys syr Symund de munfort. e sun fiz Henry. e syre Hughe le despenser e muz des Barons e des Cheualers de Engletere. Puis morust cyl Henry le Roy. e gist a Westmuster.

$|6 \mathrm{v}| \mathrm{A}\langle$ pres Henri regna Edwarde sun fiz ... $\rangle$

\section{Translation}

$|3 r|$ Here are the kings of England from the time of St Edward the Confessor up to the time of King Edward, son of King Henry III.

St Edward, by the grace of God, saw while eating on Easter Day the Seven Sleepers willingly turn from their right side to their left. And that day Godwin earl of Kent died at the table, strangled by a small piece of food. God worked many great miracles because of him in his life and afterwards.

The year of the incarnation of our Lord 1066 and the twenty-fourth of his reign, St Edward, before his death, bequeathed the kingdom of England to his nephew William the Bastard, at that time duke of Normandy. Then St Edward died, and he lies enshrined at Westminster.

|3v| After St Edward, the son of Godwin earl of Kent, Harold, reigned by force and wrongfully for nine months. Then William Bastard came and took life and kingdom from him, and conquered the land. Harold lies at Waltham.

Then William Bastard reigned for twenty-one years, then he died, and lies at Caen in Normandy.

$|4 \mathrm{r}|$ After William Bastard, his son William the Red reigned. He was shot in the New Forest. Then he died, and lies at Winchester. He had the great hall of Westminster made, and reigned for twelve years.

After William the Red, his brother the first Henry reigned for thirty-six years. He made the good laws of England, then set them down in legal form. He lies at the 
Abbey of Reading. St Thomas lifted his body from the earth and placed it before the high altar.

$|4 \mathrm{v}|$ After Henry, his nephew Stephen reigned for nineteen years, and died, and lies at Faversham.

After Stephen, the son of his sister the empress, Henry II, reigned; this Henry was then duke of Normandy. In his time, St Thomas was martyred. He reigned twenty-six or thirty-five years, then died, and lies at Fontevraud.

$|\mathrm{sr}|$ After Henry II, his son Richard reigned for ten and a half years. Returning from the Holy Land, he was taken by the duke of Austria by the aid of King Philip of France; he was delivered out of prison for one hundred thousand pounds of silver; and for this ransom, the chalices of England were taken from the churches and sold. Then he was slain by a bolt from a crossbow at the castle of Chalus, about which this verse was made: 'Christ, the plunderer of your chalice becomes the plunder of Chalus.'

|5v $\mid$ After Richard, his brother John reigned; in his time, England was placed under an interdict for six years, three quarters, and one month by Pope Innocent, on account of master Stephen Langton, whom the king did not wish to receive as archbishop of Canterbury. Then was the great war between him and the northern barons. Then Sir Louis, the son of Philip king of France, came into England. King John reigned for seventeen and a half years; then he came to Swinshed and was poisoned by a brother of that house, so it was said; and the king died at Newark, and his body was buried at Worcester.

|6r| After John, his son Henry III reigned for fifty-six years: he was nine years old when he was crowned. In his time was the battle of Evesham, where Sir Simon de Montfort was killed, and his son Henry, and Sir Hugh le Despenser, and many of the barons and knights of England. Then that King Henry died, and lies at Westminster.

$|6 \mathrm{v}| \mathrm{A}\langle$ fter Henry, his son Edward reigned ... $\rangle$ 